\title{
Ribes nigurm Seed
}

National Cancer Institute

\section{Source}

National Cancer Institute. Ribes nigurm Seed. NCI Thesaurus. Code C107353.

The oil extracted from the seeds of Ribes nigurm. Black currant oil is a source of gamma-linoleic acid and may have immune-enhancing effects. 